\title{
Hubungan Kualitas Standar Pelaporan dan Auditing Terhadap Kemajuan Pasar Modal
}

\author{
Nedi Hendri * Rahmat Fajar Ramdani*** \\ *Universitas Muhammadiyah Metro, nedi_hendri@yahoo.com, Lampung, Indonesia \\ **Universitas Muhammadiyah Metro, rahmatfajar300391@gmail.com, Lampung, Indonesia
}

\section{ARTICLE INFO}

Article history:

Received 07 Februari 2018

Received I Revised 24 Juli 2018

Accepted 29 Juli 2018

Keywords: quality of financial reporting and auditing standard, capital market development.

\section{A B S T R A C T}

The purpose of this research is to explore the relationship between quality of financial reporting and auditing standard as the proxy of institutional with capital market development in countries. This research using quality of financial reporting and auditing index score from World Economic Forum as the measurement of financial reporting and auditing standard. For capital market development this research used market capitalization at GDP as the measurment. This research used 57 countries from 5 region (Afrika, Asia, Amerika, Eropa and Pasifik) as the sample with period obseravation start from 2014 to 2016 , to analyzing the hypothesis this research used perason correlation analysis as analysis model. The result from pearson analysis showed, there is a medium relationship between quality of financial reporting and auditing standard with capital market improvement in countries. It's mean country with strong and developed capital market has high quality of financial reporting and auditing standard

Tujuan dari penelitian ini adalah untuk mengeksplorasi hubungan antara kualitas pelaporan keuangan dan standar audit sebagai proxy kelembagaan dengan pengembangan pasar modal di negara-negara. Penelitian ini menggunakan kualitas pelaporan keuangan dan skor indeks audit dari World Economic Forum sebagai pengukuran pelaporan keuangan dan standar audit. Untuk pengembangan pasar modal, penelitian ini menggunakan kapitalisasi pasar pada PDB sebagai pengukurnya. Penelitian ini menggunakan 57 negara dari 5 wilayah (Afrika, Asia, Amerika, Eropa dan Pasifik) sebagai sampel dengan periode pengamatan mulai dari tahun 2014 hingga 2016, untuk menganalisis hipotesis penelitian ini menggunakan analisis korelasi perason sebagai model analisis. Hasil dari analisis pearson menunjukkan, ada hubungan menengah antara kualitas pelaporan keuangan dan standar audit dengan peningkatan pasar modal di negara-negara. Ini berarti negara dengan pasar modal yang kuat dan maju memiliki kualitas pelaporan keuangan dan standar audit yang tinggi 
Pasar modal merupakan pasar yang memiliki peran penting dalam pengalokasian dan pendistribusian sumber daya modal bagi perusahaan yang membutuhkan modal tambahan dengan cara menjual saham maupun obligasi ke masyarakat. Selain memiliki peran bagi perusahaan, pasar modal juga menjadi sarana bagi masyarakat yang ingin mendapatkan penghasilan dari keuntungan aktivitas investasi yang keuntungannya dapat berupa deviden, pendapatan bunga hingga keuntungan dari jual beli sekuritas yang dimilikinya. Nyamakanga (2012) membuktikan terdapat hubungan yang kuat antara perkembangan pasar modal di negara Kenya dengan tingkat perumbuhan ekonomi hal ini diakibatkan karena dengan berkembangnya pasar modal akan meningkatkan kemudahan bagi perusahaan untuk memperoleh modal usaha sehingga akan meningkatkan produktivitas barang dan jasa yang tersedia di suatu negara.

Berkembangnya pasar modal dalam suatu negara dapat diukur dari besarnya nilai kapitalisasi pasar, jumlah partisipasi emiten yang tergabung dalam pasar dan jumlah turn over dari transaksi saham yang terjadi dalam suatu negara (Levine dan Zervos 1996). Selain kondisi makro yang meliputi; kondisi tingkat pendapatan perkapita, tingkat bunga, pertumbuhan financial intermediaries, stock market liquidty dan real income (Liu dan Garcia,1999; Adjasi dan Biekpe, 2006; Naceour, dkk, 2007; Masoud dan Hardaker, 2012; Sehrawat dan Giri, 2015) berkembangnya pasar modal dalam suatu negara juga didukung oleh kondisi institusional.

North (1990) menjelaskan institusi sebagai sebuah cara yang diciptakan oleh manusia untuk membatasi dan mengatur aktivitas ekonomi, bentuk politik hingga transaksi sosial, hingga akhirnya terbentuklah sebuah regulasi dan aturan - aturan yang mengikat yang dapat disebut sebagai sebuah institusi, institusi tersebut mengandung aturan - aturan formal (konstitusi negara, hukum, dan hak asasi) dan informal (adat istiadat, tradisi dan tata kerama). Dalam aspek kegiatan ekonomi, institusi di bentuk untuk menciptakan kemakmuran dan stabilitas ekonomi termasuk juga dalam pengalokasian sumber daya ekonomi melalui pasar modal.

Beberapa penelitian telah menguji pengaruh dan hubungan institusi negara terhadap perkembangan pasar modal . (La Porta dkk ,1998; Pistor dkk ,2000; Komijani dan Ahmadi ,2012) membuktikan bahwa adanya pengaruh serta hubungan dari kekuatan bentuk dan perlindungan hukum terhadap perkembangan pasar modal di suatu negara. selain itu Bayar (2016) membuktikan kondisi kualitas institusional meliputi kondisi stabilitas politik, kualitas regulator, rule of law dan control of corruption memiliki dampak positif terhadap perkembangan pasar modal di Eropa Union. Masih terdapat pengembangan yang dapat dilakukan terhadap penelitian - penelitian sebelumnya sehingga penelitian kali ini menguji kembali hubungan kualitas institusional terhadap perkembangan pasar modal disuatu negara dengan mengeksplorasi hubungan variabel baru yaitu kekuatan standard pelaporan keuangan dan auditing di dalam suatu negara.

Beberapa negara maju dan berkembang yang memiliki nilai kapitalisasi pasar yang besar seperti United States, United Kingdom, Hongkong, Japan, Belgia, Prancis, China dan Belanda memiliki nilai skor kualitas standard pelaporan dan auditing yang cukup baik seperti yang di sajikan dalam tabel 1 di bawah ini 
Tabel 1

Kualitas Kekuatan Standard Pelaporan Keuangan dan Auditing

\begin{tabular}{lll}
\hline Negara & Skor $1-7$ (best) & Rank 1/ 138 \\
\hline United Kingdom & 6,0 & 14 \\
United States & 5,8 & 19 \\
Hongkong & 6,2 & 7 \\
Japan & 5,8 & 17 \\
Belgium & 5,7 & 20 \\
Prancis & 5,6 & 25 \\
Belanda & 6,1 & 10 \\
China & 4,6 & 68 \\
\hline
\end{tabular}

Sumber : Global Competitiveness Report, 2016 - 2017

Berbeda dengan China yang merupakan salah satu negara yang tergolong memiliki pasar modal yang maju justru memiliki kualitas kekuatan standard pelaporan keuangan dan auditing yang cukup rendah 4,6 dan meduduki ranking ke 68 dari 138 negara.

Fenomena gap ini menimbulkan sebuah pertanyaan mengenai adakah hubungan kemajuan pasar modal dalam suatu negara dengan kualitas standard pelaporan keuangan dan auditing yang dimilikinya. Laporan keuangan sangat berperan penting bagi para investor dalam menentukan keputusan investasinya terutama dalam analisis fundamental sehingga untuk memfasilitasi para investor maka diperlukan ketentuan standard praktik pelaporan dan auditing untuk memastikan bahwa informasi yang disajikan dalam laporan keuangan tersebut benar - benar berkualitas dan tepat. Penelitian ini bertujuan untuk menguji adakah hubungan kualitas institusional standard pelaporan keuangan dan auditing dengan kemajuan pasar modal dalam suatu negara. Untuk mencapai tujuan tersebut maka dilakukan analisis korelasi antara nilai kapitalisasi saham dengan index skor kualitas standard pelaporan dan auditing suatu negara dengan menggunakan sampel penelitian sebanyak 57 negara di dunia. Manfaat dari penelitian ini yaitu menciptakan suatu isu penelitian baru dengan mengeksplorasi suatu variabel baru kualitas standard pelaporan keuangan dan auditing, selain itu penelitian ini memberikan kontribusi terhadap teori institusi khususnya mengenai peran berkembangnya suatu institusi terhadap perekonomian

\section{METODE}

\subsection{Jenis Penelitian}

Penelitian ini merupakan penelitian eksplorasi dengan menggunakan pendekatan kuantitatif. Penelitian eksplorasi dilakukan untuk memahami secara mendetail mengenai permasalahan yang ada dan untuk menemukan isu penelitian selanjutnya. Permasalahan yang ingin di eksplorasi dalam penelitian ini adalah mengenai adakah hubungan kualitas standard laporan keuangan dan auditing dengan kemajuan pasar modal di suatu negara

\subsection{Variabel Penelitian}

\section{a. Kapitalisasi Pasar}

Kapitalisasi pasar saham adalah jumlah akumulasi jumlah saham yang beredar dikalikan harga pasar masing - masing saham. Merujuk pada penelitian (Liu dan Garcia,1999; Adjasi dan Biekpe, 2006; Naceour, dkk, 2007; Masoud dan Hardaker, 2012; Sehrawat dan Giri, 2015) kapitalisasi pasar diukur dengan jumlah kapitalisasi pasar di bagi dengan total gross domestik produk (GDP). 


\section{b. Kualitas Standard Pelaporan Keuangan dan Auditing}

World Economic Forum (2017) menjelaskan kualitas pelaporan keuangan dan auditng sebagai salah satu kualitas institusi negara yang mengatur privat institusi dibidang tata kelola perusahaan. Merujuk pada World Economic Forum kualitas pelaporan keuangan dan auditing diukur dengan index skor yang memiliki interval 1 hingga tujuh $(1-7)$ semakin tinggi skor menjelaskan semakin baik kualitas standard pelaporan dan auditing dalam suatu negara

\subsection{Data, Populasi dan Sampel Penelitian}

\section{a. Data}

Penelitian ini menggunakan data sekunder yang diperoleh melalui teknik dokumentasi. dokumen - dokumen yang digunakan dalam penelitian ini yaitu dokumen laporan global competiteveness report yang berisi data mengenai index skor kualitas standard pelaporan keuangan dan auditing yang diperoleh dari situs resmi World Economic Forum. Dokumen berikutnya yaitu laporan indikator negara yang berisi data kapitalisasi pasar yang diperoleh dari situs Bank Dunia. Data yang digunakan dalam penelitian ini meliputi data periode tahun 2014 hingga tahun 2016.

\section{b. Populasi dan Sampel}

Populasi yang digunakan dalam penelitian ini adalah seluruh negara di seluruh benua, penelitian ini menggunakan 57 negara sebagai sampel penelitian. Pemilihan sampel berdasarkan pada teknik purposive sampling dengan kriteria negara yang dapat menjadi sampel yaitu; pertama, memiliki pasar modal, kedua, terdapat kelengkapan dokumen data mengenai kapitalisasi pasar saham dan kulitas pelaporan keuangan dan auditing. Pada tabel 2 di bawah ini menyajikan negara - negara yang menjadi sampel berdasarkan pada benua.

Tabel 2

Sampel Penelitian Berdasarkan Benua

\begin{tabular}{|c|c|c|c|c|c|c|c|c|c|}
\hline \multicolumn{2}{|r|}{ Afrika } & \multicolumn{2}{|r|}{ Amerika } & \multicolumn{2}{|r|}{ Asia } & \multicolumn{2}{|r|}{ Eropa } & \multicolumn{2}{|r|}{ Pasifik } \\
\hline 1. & Cote d'Ivoire & 1. & Argentina & 1. & Bahrain & 1. & Austria & 1. & Australia \\
\hline 2. & Egypt, Arab Rep. & 2. & Brazil & 2. & China & 2. & Belgium & 2. & New Zealand \\
\hline 3. & Mauritius & 3. & Canada & 3. & Hong Kong & 3. & Cyprus & & \\
\hline 4. & Morocco & 4. & Chile & 4. & India & 4. & France & & \\
\hline 5. & Nigeria & 5. & Colombia & 5. & Indonesia & 5. & Germany & & \\
\hline 6. & Oman & 6. & Mexico & 6. & Iran, Islamic Rep. & 6. & Greece & & \\
\hline 7. & Tunisia & 7. & Panama & 7. & Israel & 7. & Hungary & & \\
\hline & & 8. & Peru & 8. & Japan & 8. & Ireland & & \\
\hline & & 9. & United States & 9. & Jordan & 9. & Luxembourg & & \\
\hline & & & & 10. & Kazakhstan & 10. & Malta & & \\
\hline & & & & 11. & Korea, Rep. & 11. & Netherlands & & \\
\hline & & & & 12. & Lebanon & 12. & Norway & & \\
\hline & & & & 13. & Malaysia & 13. & Poland & & \\
\hline & & & & 14. & Philippines & 14. & Portugal & & \\
\hline & & & & 15. & Qatar & 15. & Slovenia & & \\
\hline & & & & 16. & Saudi Arabia & 16. & Spain & & \\
\hline & & & & 17. & Singapore & 17. & Switzerland & & \\
\hline & & & & 18. & Sri Lanka & 18. & Turkey & & \\
\hline & & & & 19. & Thailand & & & & \\
\hline & & & & 20. & United Arab Emirates & & & & \\
\hline & & & & 21. & Vietnam & & & & \\
\hline
\end{tabular}

Sumber : Data sekunder yang diolah tahun 2018 


\subsection{Analisis Korelasi (Pearson Correlation)}

Untuk menjawab hipotesis, penelitian ini menggunakan analisis korelasi sederhana. Analisis korelasi sederhana yang digunakan untuk menganalisis hubungan antar variabel pada penelitian ini yaitu analisis pearson corelation. Alasan dipilihnya analisis pearson corelation karena pada penelitian ini hanya bermaksud menguji dua variabel interdependen yang memiliki data metrik yang skala pengukuran terdiri dari skala interval dan rasio (Ghozali, 2012). Pengambilan keputusan kekuatan hubungan serta arah hubungan berdasarkan pada interval -1 hingga +1 , jika semakin mendekati \pm 1 menunjukan semakin besarnya hubungan baik hubungan negatif maupun positif. Berikut merupakan interval hasil pengujian korelasi menurut sugiyono (2009)

1. $-0,199=$ sangat rendah

2. $0,20-0,3999=$ rendah

3. $0,40-0,5999=$ sedang

4. $0,60-0,799=$ kuat

5. $0,80-1,000=$ sangat kuat

\subsection{Perkembangan Institusional dan Kemajuan Pasar Modal}

North (1991) menjelaskan institusi sebagai sebuah cara yang diciptakan oleh manusia untuk membatasi dan mengatur aktivitas ekonomi, bentuk politik hingga transaksi sosial, hingga akhirnya terbentuklah sebuah regulasi dan aturan - aturan yang mengikat yang dapat disebut sebagai sebuah institusi, institusi tersebut mengandung aturan - aturan formal (konstitusi negara, hukum, dan hak asasi) dan informal (adat istiadat, tradisi dan tata kerama). Setiap negara akan memiliki bentuk institusi masing - masing dan bentuk tersebut akan selalu berevolusi dan dipengaruhi oleh karakteristik dan kebutuhan negara tersendiri. Salah satu penyebab berevolusinya institusi negara yaitu dalam menunjang kegiatan perekonomian dalam hal ini adalah pasar modal

Pasar modal merupakan salah satu bagian dari financial market yang secara khusus menjadi tempat dimana menyediakan arena bagi para investor untuk melakukan transaksi jual beli sekuritas keuangan jangka panjang seperti sekuritas modal berupa saham dan sekuritas hutang berupa obligasi (Alan, 2004). Salah satu institusi negara yang berperan dan mendukung dan menunjang kegiatan dalam pasar modal adalah institusi yang mengatur mengenai standard pelaporan keuangan dan jasa auditing. World Economic Forum (2017) mengklasifikasikan institusi dalam suatu negara menjadi dua bentuk yaitu public institution dan privat institution. Standard pelaporan keuangan dan auditing merupakan bagian dari privat institution yang mengatur lingkup tata kelola perusahaan mengenai peraturan praktik pelaporan keuangan dan jasa audit.

Laporan keuangan merupakan sebuah alat komunikasi yang digunakan oleh pihak manajemen untuk menginformasikan kondisi keuangan serta kinerja perusahaan kepada para pemilik modal atau shareholder, sehingga menurut International Assosiation Standard Board (IASB) bahwa tujuan utama pelaporan keuangan adalah untuk memberikan informasi yang berguna bagi pengambilan keputusan para investor (Kieso dkk, 2014). Untuk memberikan keyakinan terhadap informasi yang disajikan dalam laporan keuangan yang disusun oleh pihak manajemen maka diperlukan adanya pemeriksaan audit yang dilakukan oleh profesional yang independen dalam hal ini adalah akuntan publik atau auditor dan hasil 
pemeriksaan tersebut berupa pendapat atas kewajaran dari laporan keuangan yang telah diaudit (Mulyadi, 2009).

Investor memerlukan laporan keuangan sebagai sumber informasi utama analisis fundamental yang digunakan untuk pengambilan keputusan investasi sehingga untuk memfasilitasi para investor beberapa upaya dilakukan oleh negara untuk meningkatkan kualitas pelaporan keuangan serta auditing. Sebuah upaya negara dalam meningkatkan kualitas intstitusi pelaporan kauangan dan auditing yaitu dengan cara mengkonvergensi standard international IFRS yang telah terbukti mampu menarik para investor asing yang dibuktikan oleh penilitian Amiram (2012). Berdasarkan hasil penelitian tersebut dapat diasumsikan bahwa untuk menarik para investor asing dalam suatu negara maka perlu memfasilitasinya dengan standard pelaporan keuangan yang kuat dan berkualitas. Banyaknya investor yang berinvestasi dan salah satunya investor asing menunjukkan majunya pasar modal dalam suatu negara.

Berdasarkan penjelasan teori dan konsep dan dukungan penelitian, dapat diasumsikan bahwa negara yang memiliki pasar modal yang maju juga didukung oleh kualitas standard akuntansi dan auditing yang baik sehingga pada penelitian ini disusunlah kerangka pemikiran serta hipotesis sebagai berikut:

\section{Gambar 1 \\ Kerangka Pemikiran}

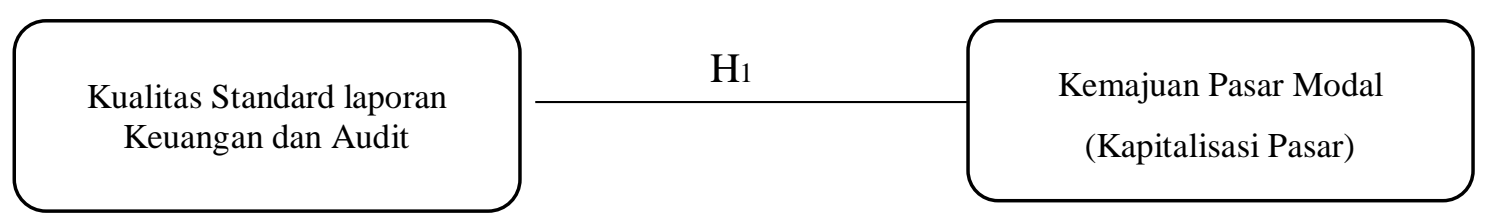

Hipotesis 1 : Terdapat hubungan kualitas standard akuntansi dan auditing terhadap kemajuan pasar modal dalam suatau negara

\section{HASIL DAN PEMBAHASAN}

\subsection{Pengujian Hipotesis (Pearson Correlation)}

Tabel 3

Pengujian Analisis Pearson Corelation

\begin{tabular}{llrr}
\multicolumn{3}{c}{ Correlations } \\
\hline LNCAPAT & LNCAPAT & financereport \\
& Pearson Correlation & 1 &, $571^{* *}$ \\
& Sig. (2-tailed) & &, 000 \\
financereport & $\mathrm{N}$ & 171 & 171 \\
& Pearson Correlation &, $571^{* *}$ & 1 \\
& Sig. (2-tailed) &, 000 & 171 \\
& $\mathrm{~N}$ & 171 & \\
\hline
\end{tabular}

Sumber : Data sekunder yang diolah tahun 2018 


\subsection{Hubungan Kualitas Standard Pelaporan Keuangan dan Auditing Terhadap Kemajuan Pasar Modal}

Berdasarkan hasil pengujian pada tabel 3 diatas, diperoleh nilai pearson correlation dengan arah positif 0,571 dengan nilai signifikansi $0,000<0,05$. Hasil ini membuktikan bahwa terdapat hubungan yang positive dan signifikan antara kualitas pelaporan keuangan dan auding dengan kemajuan pasar modal dalam suatu negara. Berdasarkan hasil ini kekuatan hubungan antara variabel masuk dalam kategori hubungan yang sedang karena nilai positif korelasi 0,571 berada pada interval 0,40 - 0,5999. Berdasarkan hasil ini dapat ditarik kesimpulan bahwa hipotesis satu diterima .

Hasil pembuktian ini membuktikan isu penelitian bahwa negara yang memiliki pasar modal yang maju di fasilitasi oleh standard pelaporan keuangan dan auditing yang berkualitas. Hasil ini mendukung teori institusional North (1990) bahwa salah satu tujuan di bentuknya institusi oleh negara adalah untuk mengembangkan perekonomian. Pada penelitian ini dibuktikan bahwa untuk memfasilitasi para investor dalam prosess pengambilan keputusan, negara berusaha untuk selalu meningkatkan peraturan dan kekuatan institusinya dalam hal ini privat institution yang diwujudkan dalam bentuk standard pelaporan dan auditing yang lebih berkualitas sehingga negara yang memiliki pasar modal yang berkembang diasumsikan juga memiliki kualitas standard pelaporan keuangan yang berkualitas.

\section{KESIMPULAN}

Berdasarkan hasil pengujian hipotesis telah dibuktikan secara statistik bahwa terdapat hubungan sedang antara kualitas pelaporan keuangan dan auditing dengan kemajuan pasar modal. Penelitian ini mampu menunjang teori institusi yang dikembangkan oleh North (1990) yang menjelaskan bahwa institusi berupa standard pelaporan keuangan dan auditing dibentuk dan diciptakan untuk kemakmuran negara salah satunya adalah untuk menunjang aktivitas perekonomian melalui pasar modal. Penelitian ini memiliki kelemahan dalam pengumpulan hasil sampel yang tidak dapat diperoleh secara maksimal, hal tersebut dikarenakan aksesbilitas terhadap dokumen yang mencakup data penelitian mengenai jumlah kapitalisasi pasar terhadap GDP yang masih sangat terbatas. Penelitian ini hanya merupakan penelitian ekplorasi yang hanya menguji hubungan sederhana antar variabel, penelitian ini tidak menganalisis secara mendalam hubungan sebab akibat antara dua variabel

Saran untuk penelitian berikutnya yaitu; untuk mengembangkan penelitian dengan cara melakukan analisis lanjutan untuk mencari hubungan kasualitas dengan menggunakan Granger Casuality. Dengan dilakukan pengujian Granger Casuality akan diketahui hubungan sebab akibat sehingga akan diketahui manakah diantara kualitas standard dan kemajuan pasar modal yang menjadi saling mempengaruhi dan dipengaruhi

\section{DAFTAR PUSTAKA}

Adjasi, C. K. D., Biekpe, N. B. 2006. "Stock market development and economic growth: The case of selected African countries". African Development Review 18(1): 144-161.

Alan, Griffith., Stuart, Wall. 2004. Applied Economics, Tenth Edition. England: Prantice Hall

Amiram, D. 2012. "Financial information globalization dan foreign investment decisions". Journal of International Accounting Research, 11(2), 25-37.

Bayar, Yilmaz. 2016. "Institiounal determinant of stock market development in european union transition economics". The romanian economic journal, No 61 pp $211-226$. 
Ghozali, Imam. 2011. Aplikasi Analisis Multivariate dengan program SPSS, cetakan kelima. Semarang: Badan Penerbit Universitas Diponegoro.

Kieso, Donald.E., Weygandt, Jerry. J.,Warfield, Terry. D. 2014. Intermediate Accounting, Fiftenth Edition. United States: Wiley \& Sons

Komijani, Akbar., dan Ahmadi, Habib. Soheili. 2012.”Analysis Role Of Protecting Shareholder Rights in Expanding Stock Market in Selected Developing Countires”. International journal of bussiness and social science, vol 13 no 17

La Porta, R., Lopez-de-Silanes, F., Shleifer, A., and Vishny, R.W. 1998. "Law and finance”. Journal of Political Economy 106: 1113-1155.

Levine, R., dan Zervos, S. 1996. "Stock Market Development and Long Run Growth. World Bank Policy Working Paper, 1582, 34-55.

Masoud, N., Hardaker, G. 2012. "The impact of financial development on economic growth". Studies in Economics and Finance 29(3): 148 - 173.

Mulyadi. 2009. Auditing. edisi enam. Jakarta: salemba empat

Neceour, Ben. Sammy., Ghazouani, Samir., Omran, Mohamed. 2007. Manejerial Economics vol, 33, no pp 477- 489, emerald insight.

North, D. 1990. Institutions, institutional change, and economic performance. New York: Norton

Nyamakanga, Raymond. 2013. "Relation stock market development and economic growth in kenya". Thesis, University of Nairobi.

Pistor, K., Raiser, M., Gelfer, S. 2000. "Law and finance in transition economies". Economics of Transition 8, 325-368.

Sehrawat, M., Giri, A. K. 2015. Financial development and economic growth: empirical evidence from India. Studies in Economics and Finance 32(3): 340 - 356.

Sugiyono. 2009. Metode Penelitian Kuantitatif. Bandung: Alfabeta

Valeriano, F. Garcia., dan Linliu. 1999. "Macro economic determinant of stock market development". Journal of aplied economics, vol II No. 129 - 59.

World Bank. 2018. World Development Indicators. Retrieved 2015, from The World Bank: http://data.worldbank.org/data-catalog/world-development-indicators

World Economic Forum, 2017. Global Competitiveness Report, Geneva. 